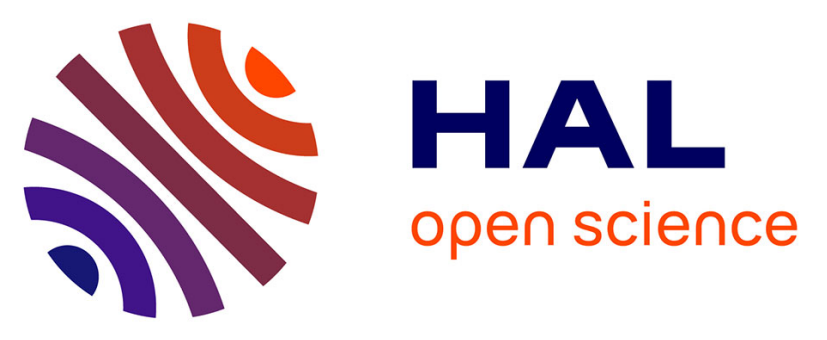

\title{
Regioselective $\mathrm{C}-\mathrm{H}$ amination of free base porphyrins via electrogenerated pyridinium-porphyrins and stabilization of easily oxidized amino-porphyrins by protonation
}

Asmae Bousfiha, Abdou K D Dimé, Amelle Mankou-Makaya, Julie

Echaubard, Mathieu Berthelot, Hélène Cattey, Anthony Romieu, Julien

Roger, Charles H. Devillers

\section{- To cite this version:}

Asmae Bousfiha, Abdou K D Dimé, Amelle Mankou-Makaya, Julie Echaubard, Mathieu Berthelot, et al.. Regioselective $\mathrm{C}-\mathrm{H}$ amination of free base porphyrins via electrogenerated pyridinium-porphyrins and stabilization of easily oxidized amino-porphyrins by protonation. Chemical Communications, 2020, 56 (6), pp.884-887. 10.1039/c9cc07351e . hal-03419593

\section{HAL Id: hal-03419593 \\ https://hal.science/hal-03419593}

Submitted on 8 Nov 2021

HAL is a multi-disciplinary open access archive for the deposit and dissemination of scientific research documents, whether they are published or not. The documents may come from teaching and research institutions in France or abroad, or from public or private research centers.
L'archive ouverte pluridisciplinaire HAL, est destinée au dépôt et à la diffusion de documents scientifiques de niveau recherche, publiés ou non, émanant des établissements d'enseignement et de recherche français ou étrangers, des laboratoires publics ou privés. 


\section{Journal Name}

\section{COMMUNICATION}

\section{Regioselective C-H Amination of Free Base Porphyrins via Electrogenerated Pyridinium-Porphyrins and Stabilization of Easily Oxidized Amino-Porphyrins by Protonation}

Received 00th January 20xx, Accepted 00th January 20xx

DOI: $10.1039 / \times 0 \times x 00000 x$
Asmae Bousfiha, ${ }^{a}$ Abdou K. D. Dimé, ${ }^{b}$ Amelle Mankou-Makaya, ${ }^{a}$ Julie Echaubard, ${ }^{a}$ Mathieu Berthelot, ${ }^{a}$ Hélène Cattey, ${ }^{a}$ Julien Roger, ${ }^{a}$ Charles H. Devillers*a

www.rsc.org/

Four free base aminoporphyrins were synthesized in two steps via regioselective anodic nucleophilic substitution with pyridine followed by ring opening of the electrogenerated pyridinium with piperidine. The X-ray crystallographic structure of the unstable 2aminotetraphenylporphyrin was solved. Protonation of this latter compound leads to the stable diiminium porphyrin salt.

For many decades, porphyrins have attracted considerable attention due to their involvement in natural processes (photosynthesis, $\mathrm{O}_{2}$ transport in blood...) and their recent applications in various research fields such as photovoltaic solar cells, non-linear optical materials, photodynamic therapy and molecular electronics. ${ }^{1}$ To finely tune and improve the performance of porphyrin-based materials, peripheral functionalization of the porphyrin ring with judicious (hetero)atoms or molecular fragment(s) is essential. In particular, the introduction of a nitrogen atom directly connected to the meso or the $\beta$ position(s) of the porphyrin core induces intense alterations of the electronic, optical, and electrochemical properties. Among this family, meso- or $\beta$ aminoporphyrins are an important class of molecules that have found various applications such as dye sensitized solar cell. ${ }^{2}$ They have been synthesized via the transition metal-catalyzed $\mathrm{C}-\mathrm{N}$ bond formation from haloporphyrins, ${ }^{3}$ the oxidative coupling of arylamines with 5,15-diarylporphyrins, ${ }^{4}$ and $\mathrm{S}_{N} A r$ reactions between primary or secondary alkyl/aryl amines with chloro-, ${ }^{5}$ nitro- ${ }^{6}$ and bromoporphyrins. ${ }^{7}$ Another strategy consists in the chemical transformation/functionalization of $\mathrm{NH}_{2}$-porphyrins. ${ }^{8}$ Thus, $\mathrm{NH}_{2}$-porphyrins could be attractive precursors if their synthesis is straightforward, efficient and performed in mild conditions. Currently, the main strategy used for the synthesis of $\mathrm{NH}_{2}$-porphyrins consists in the porphyrin

\footnotetext{
a. Institut de Chimie Moléculaire de I'Université de Bourgogne UMR6302, Université de Bourgogne Franche-Comté, 9 avenue Alain Savary, 21078 Dijon, France. Email:charles.devillers@u-bourgogne.fr.

b. Département de Chimie, UFR SATIC, Université Alioune Diop de Bambey, Senegal.

† Footnotes relating to the title and/or authors should appear here.

Electronic Supplementary Information (ESI) available. See DOI: 10.1039/x0xx00000x
}

nitration then reduction of the nitro function affording the aminoporphyrin. The nitration step is generally performed using $\mathrm{NO}_{2} / \mathrm{N}_{2} \mathrm{O}_{2}$ gas, ${ }^{9} \mathrm{AgNO}_{2} / \mathrm{I}_{2},{ }^{10}$ reaction of the porphyrin cation radical with nitrite, ${ }^{10 a, 11}$ or acidic conditions $\left(\mathrm{HNO}_{3},{ }^{8 a, 12} \mathrm{NO}_{2} \mathrm{BF}_{4}\right.$ in $\mathrm{H}_{2} \mathrm{SO}_{4},{ }^{12 a} \mathrm{Zn}\left(\mathrm{NO}_{3}\right)_{2}{ }^{13}$ or $\mathrm{Cu}\left(\mathrm{NO}_{3}\right)_{2}$ in $\mathrm{Ac}{ }_{2} \mathrm{O}, 8 \mathrm{i}, 12 \mathrm{a}, 14 \mathrm{TFA} / \mathrm{NaNO}_{2},{ }^{15}$ $\mathrm{LiNO}_{3}$ in $\mathrm{AcOH} / \mathrm{Ac}_{2} \mathrm{O}^{8 \mathrm{~g}, 16}$ ). Moreover, for di/tri/tetra-meso-free porphyrins and 5,10,15,20-tetraarylporphyrins, the perfectly selective mono-nitration is hard to reach as significant amount of starting and/or dinitrated porphyrins are systematically observed in the crude mixture. Considering the nitro reduction step, two main reacting conditions are reported: $\mathrm{NaBH}_{4}$ with $\mathrm{Pd} / \mathrm{C}^{10 \mathrm{~b}}$ and $\mathrm{SnCl}_{2} / \mathrm{HCl}$. ${ }^{12 \mathrm{a}}$ With $\mathrm{NaBH}_{4} \mathrm{Pd} / \mathrm{C}$, metalloporphyrins $(\mathrm{M}=\mathrm{Ni}(\mathrm{II}), \mathrm{Cu}(\mathrm{II}), \mathrm{Zn}(\mathrm{II}))$ are more suitable since degradation may occur with free base porphyrins. ${ }^{17} \mathrm{As} \mathrm{SnCl}_{2}$ is associated with $\mathrm{HCl}$ its use is only limited to acid-resistant functions/metals on the porphyrin. An alternative route to $\mathrm{NH}_{2}$-porphyrin proposed by Arnold and co-workers involves a palladiumcatalyzed $\mathrm{C}-\mathrm{N}$ bond formation reaction (Buchwald-Hartwig reaction) of $\mathrm{Ni}$ (II) meso-bromoporphyrin with hydrazine. ${ }^{18}$ However, the yield of the aminoporphyrin is fair (51\%) and the reaction was only reported with the $\mathrm{Ni}(\mathrm{II})$ porphyrin complex which limits its usefulness. More recently, a metal-free amination route of meso-bromo-di-aryl free base and metalated ( $\mathrm{Ni}(\mathrm{II}), \mathrm{Cu}(\mathrm{II}), \mathrm{Pd}(\mathrm{II}))$ porphyrins was reported by Yamashita, Sugiura and co-workers. ${ }^{8 \mathrm{~h}}$ This two-step one-pot synthesis involved the nucleophilic attack of an azide excess (10 eq.) onto meso-bromoporphyrins ( $\mathrm{S}_{N} \mathrm{Ar}$ reaction) followed by the in situ reduction of the meso-azidoporphyrin to the corresponding $\mathrm{NH}_{2}$-porphyrin with sodium ascorbate. The reaction is efficient $(80-90 \%$ yield) but the starting monobrominated precursor is difficult to obtain in a pure form and large amounts since the direct meso-monobromination of 5,15diarylporphyrins leads to mixtures containing the starting porphyrin, mono-brominated and dibrominated porphyrins which are generally hard to separate by column chromatography. ${ }^{19}$ Recently, Yoshida and co-workers have reported the electrochemical $\mathrm{C}-\mathrm{H}$ amination of benzene-, naphthalene- and biphenyl-based derivatives. ${ }^{20}$ This two-step 


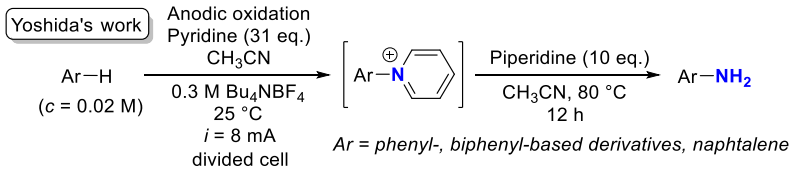

Scheme 1 Two-step amination reaction for aromatic compounds..$^{20}$

reaction starts with an anodic nucleophilic substitution of the aromatic molecules in presence of an excess of pyridine, leading to the non-isolated pyridinium intermediate (Scheme 1). Then, the nucleophilic attack of piperidine on the pyridinium moiety leads to its ring opening affording the aromatic primary amine. $^{20}$ We reasoned that, given the very high (regio)selectivity of the (electro)chemical pyridination reaction, in particular for porphyrins, ${ }^{21}$ this alternative amination route could be relevant in porphyrin chemistry. Thus, we report herein the efficient amination of 5,10,15,20tetraphenylporphyrin ( $\mathbf{H}_{\mathbf{2}}$ TPP), 5,15-di-( $p$-tolyl)porphyrin $\left(\mathbf{H}_{2} \mathbf{D T P}\right)$, porphine, the fully unsubstituted porphyrin $\left(\mathrm{H}_{\mathbf{2}} \mathbf{P}\right)$ and 2,7,12,17-tetra-tert-butylporphyrin $\quad\left(\mathbf{H}_{\mathbf{2}}\right.$ TTBP) free bases affording the corresponding already known $\mathbf{H}_{2}$ TPP- $\mathbf{N H}_{2}$ and the original $\mathbf{H}_{\mathbf{2}}$ DTP- $\mathbf{N H}_{\mathbf{2}}, \mathbf{H}_{\mathbf{2}} \mathbf{P}-\mathbf{N H}_{\mathbf{2}}$ and $\mathbf{H}_{\mathbf{2}} \mathbf{T T B P}-\mathbf{N H}_{\mathbf{2}}$ respectively (Scheme 2). Free base porphyrins have been selected since, though less soluble, they are generally more easily available than their corresponding complexes and after amination, any metal can be inserted in the porphyrin core. Thus, the additional demetalation-remetalation steps are avoided.

Considering the pyridination reaction, initial attempts were made following Yoshida's reacting conditions (Scheme 1). However, the starting free base porphyrins are not soluble at al in acetonitrile (excepted $\mathbf{H}_{\mathbf{2}}$ TTBP which is only slightly soluble) and thus an important screening of the best experimental conditions was performed for each porphyrin. As much as possible we endeavored to decrease the amounts of pyridine and solvent(s) (typically, pyridination reactions were performed in saturated porphyrin solution) and to simplify the electrochemical cell setup (work at constant current, one compartment cell configuration). Besides, we have chosen tetraethylammonium tetrafluoroborate $\left(\mathrm{TEABF}_{4}\right)$ supporting

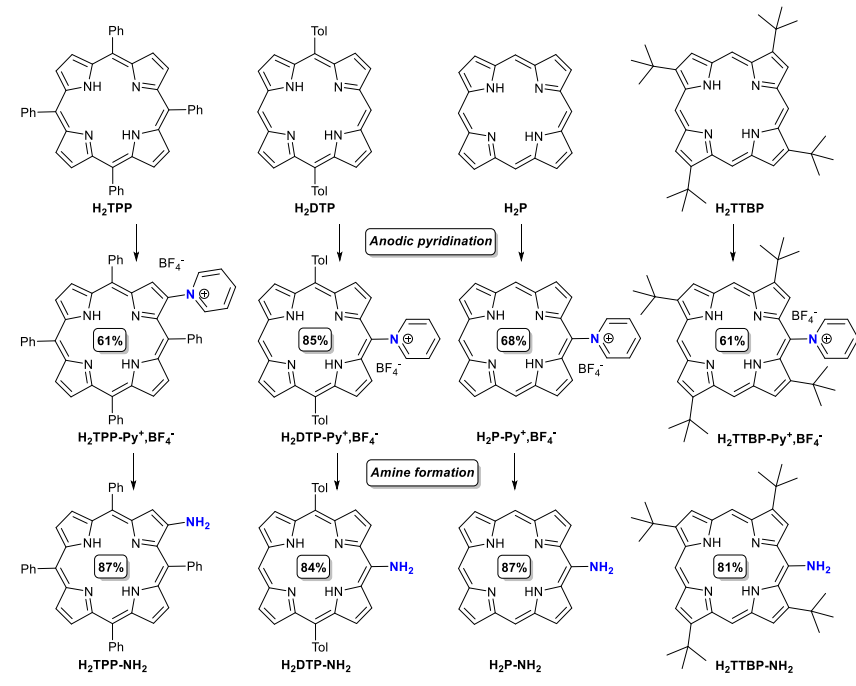

Scheme 2 Pyridinium-porphyrins and aminoporphyrins synthesized in this work. electrolyte as it is easily removable at the end of the reaction by water washings. The electrochemical $\beta$-pyridination of $\mathbf{H}_{\mathbf{2}}$ TPP was first reported by Giraudeau and co-workers. ${ }^{21 c}$ Though the reported yield was high (85\%), they performed the reaction on $40 \mathrm{mg}$ of porphyrin, in a three compartment cell configuration, at constant potential, using large excess of pyridine (760 eq.), under very diluted conditions $\left(\left[\mathrm{H}_{2} \mathrm{TPP}\right]=2.6 \times 10^{-4} \mathrm{M}\right)$. So, for $\mathbf{H}_{\mathbf{2}}$ TPP, we have chosen to work in a two compartment cell configuration (anode and cathode are in the same compartment), in a $\mathrm{CH}_{2} \mathrm{Cl}_{2}$ /acetonitrile (DCM/ACN) mixture (4/1 $\mathrm{v}: \mathrm{v}$ ), with saturated solution (equivalent to a theoretical concentration of $\left.\left[\mathrm{H}_{2} \mathrm{TPP}\right]=5.0 \times 10^{-3} \mathrm{M}\right)$. To avoid unwanted reaction from occurring at the cathode, 2.0 eq. of $\mathrm{HBF}_{4} \cdot \mathrm{Et}_{2} \mathrm{O}$ were added. Thus only hydrogen evolution takes place at the cathode. For a given applied potential ( $E_{\mathrm{app}}=1.10 \mathrm{~V} v \mathrm{vs}$. SCE), the amount of pyridine and charge were optimized. Too low amounts of nucleophile (entries 2-4, Table S1) or charge (entry 1 , Table S1) were prejudicial for the yield. Working with 100 eq. of pyridine and $4.0 \mathrm{~F} . \mathrm{mol}^{-1}$ were the best conditions in our hands and affords $61 \%$ yield of $\mathbf{H}_{\mathbf{2}} \mathbf{T P P}-\mathbf{P y}^{+}, \mathbf{B F}_{4}{ }^{-}$. Further increase of the charge (entry 7, Table S1) or the amount of nucleophile (entry 6 , Table S1) leads to lower yield. To allow for a better availability of this electrochemical pyridination method, electrolysis was also performed in a one compartment cell applying a constant current $\left(i_{\text {app }}=2.0 \mathrm{~mA}\right.$ ) with the optimized pyridine and charge amounts (entry 8, Table S1). In these conditions, $\mathbf{H}_{\mathbf{2}} \mathbf{T P P}-\mathbf{P y}^{+}, \mathbf{B F}_{\mathbf{4}}$ (Scheme 2 ) was obtained in $51 \%$ yield.

Similar optimizations were then applied to $\mathbf{H}_{2}$ DTP. In a two compartment cell, applying $1.03 \mathrm{~V}$ vs. SCE (first oxidation peak) with 10 eq. of pyridine, 2.75 F.mol ${ }^{-1}$ were passed until the current decreased to the residual current. In these conditions, the original $\mathbf{H}_{2} \mathbf{D T P}-\mathbf{P y}^{+}, \mathbf{B F}_{4}^{-}$(Scheme 2) was obtained in $75 \%$ yield (entry 1 , Table $\mathrm{S} 2$ ). In the same conditions but increasing the DCM/ACN ratio $(9: 1 \mathrm{v}: \mathrm{v})$ to increase the solubility of the porphyrin, the yield increased slightly to $77 \%$ (entry 2, Table S2). As the pyridination reaction was already efficient, the amount of pyridine was decreased down to two equivalents (entry 3 , Table S2). To our surprise, the yield was even higher (83\%) and the passed charged was close to the theoretical one $\left(2.20 \mathrm{~F} . \mathrm{mol}^{-}\right.$ 1 vs 2.00 F. $\left.\mathrm{mol}^{-1}\right)$. Besides, the desired pyridinium $\mathrm{H}_{2}$ DTP$\mathbf{P y}^{+}, \mathbf{B F}_{4}{ }^{-}$was also obtained in very good yield (85\%) after abstraction of $2.47 \mathrm{~F}$, in a one compartment cell applying a constant current of $2.0 \mathrm{~mA}$ (entry 4 , Table S2). These results are particularly remarkable since the pyridination of magnesium(II) porphine (MgP) had to be performed in pyridine as solvent (>8000 eq.) to prevent the competitive oligomerizationpolymerization from occurring. ${ }^{21 e}$

Functionalization of $\mathbf{H}_{\mathbf{2}} \mathbf{P}$ is very rare. In particular, the preparation and characterization of $\mathbf{H}_{\mathbf{2}} \mathbf{P}-\mathbf{N H}_{\mathbf{2}}$ have never been reported. The selective mono-pyridination $\mathbf{H}_{2} \mathbf{P}$ is challenging since 1 ) four meso-free and eight $\beta$-free positions are available for substitution and 2) $\mathbf{H}_{2} \mathbf{P}$ exhibits a very low solubility in organic solvents $\left(\leq 5 \times 10^{-4} \mathrm{M}\right)$. The best experimental conditions developed for $\mathbf{H}_{\mathbf{2}}$ DTP were first tested on $\mathbf{H}_{\mathbf{2}} \mathbf{P}$. Unfortunately, even if the reaction worked, a significant amount (10-20\%) of chlorinated side-product was systematically produced and was not separable from the desired compound (entry 1, Table S3). 
In this particular case, pyridine had to be chosen as solvent to avoid chlorination of $\mathbf{H}_{\mathbf{2}} \mathbf{P}$. Fortunately, the solubility of $\mathbf{H}_{\mathbf{2}} \mathbf{P}$ in pyridine is fair and when applying a potential corresponding to its first oxidation in a three compartment cell $\mathbf{H}_{\mathbf{2}} \mathbf{P}-\mathbf{P y}^{+}, \mathbf{B} \mathbf{F}_{\mathbf{4}}$ was produced and isolated in $68 \%$ yield (entry 2 , Table $\mathrm{S} 3$ ).

To further extend the scope of the pyridination reaction, the more hindered but more soluble $\mathbf{H}_{2}$ TTBP was selected. As for $\mathbf{H}_{2} \mathbf{P}$, when $\mathrm{CH}_{2} \mathrm{Cl}_{2}$ was used as co-solvent, non-separable chlorinated side-products were formed (entry 1, Table S4). In pyridine as solvent, when applying the first oxidation potential $\left(E_{\text {app }}=1,10 \mathrm{~V} / \mathrm{SCE}\right), \mathbf{H}_{\mathbf{2}} \mathrm{TTBP} \mathbf{\mathrm { P }} \mathbf{P y}^{+}, \mathbf{B F}_{\mathbf{4}}{ }^{-}$was obtained in $61 \%$ yield (entry 2, Table S4). More interestingly, as $\mathbf{H}_{2}$ TTBP is slightly soluble in acetonitrile, an electrolysis was attempted in acetonitrile with only two equivalents of pyridine. In these conditions, $\mathbf{H}_{2} \mathbf{T T B P}-\mathbf{P y}^{+}, \mathbf{B F}_{4}^{-}$was also isolated in $61 \%$ yield (entry 3, Table S4). Suitable crystals for X-ray analysis were grown from the corresponding zinc(II) complex (Fig. 2, right). This crystallographic structure confirms that the pyridinium attacks the meso position.

The subsequent amine formation via the pyridinium ringopening reaction was then developed. Thus, an acetonitrile solution of the pyridinium-porphyrin was heated to $70^{\circ} \mathrm{C}$ under an argon atmosphere and after stabilization of the temperature, 10 eq. of piperidine were added to the solution. The full conversion of the initial pyridinium-porphyrins provides the amino-porphyrins in $20 \mathrm{~min}$. for $\mathbf{H}_{\mathbf{2}} \mathbf{T P P}-\mathbf{N H}_{\mathbf{2}}$ (87\% yield), $2 \mathrm{~h}$ for $\mathbf{H}_{2}$ DTP- $\mathbf{N H}_{2}$ (84\% yield) and $\mathbf{H}_{\mathbf{2}} \mathbf{P}-\mathbf{N H}_{\mathbf{2}}$ (87\% yield) and $70 \mathrm{~h}$ for $\mathbf{H}_{2}$ TTBP- $\mathrm{NH}_{2}$ (81\% yield).

As other electron-rich aminoporphyrins, $8 \mathrm{~h} \mathbf{H}_{\mathbf{2}} \mathbf{T P P}-\mathbf{N H}_{\mathbf{2}}$ is known to be unstable ${ }^{10 b}$ as it is rapidly (photo)-oxidized into 2,3dioxochlorin (Scheme 3).8i,22 Thus it has to be prepared and used readily in the next step without purification. This instability is a key factor which limits its utility in the design of more elaborated functionalized porphyrins. Birin, Guilard and coworkers have noted that when the phenyl substituents bear electron-withdrawing substituents such as fluorine, the corresponding $\beta$-aminoporphyrins are more stable and can be purified by column chromatography. ${ }^{8 i}$ We reasoned that protonation of the free base aminoporphyrin could lead to its stabilization due to the strong electron-withdrawing effect of the added proton(s) on the amine/imine function(s). To our delight, the idea works well as the addition of 2.2 eq. of $\mathrm{HBF}_{4}$ to a $\mathrm{CH}_{2} \mathrm{Cl}_{2}$ solution of the porphyrin at $\mathrm{RT}$ leads to the quantitative diprotonation of the inner imine functions of the porphyrin $\left(\left[\mathrm{H}_{4} \mathrm{TPP}-\mathrm{NH}_{2}\right]^{2+}, \mathbf{2 B F}_{4}{ }^{-}\right.$, Scheme $2, \mathbf{9 2} \%$ isolated yield, see the ${ }^{1} \mathrm{H}$ NMR monitoring of the protonation in Fig. S1). Indeed, on the ${ }^{1} \mathrm{H}$ $\mathrm{NMR}$ spectrum in $\left(\mathrm{CD}_{3}\right)_{2} \mathrm{SO}$, the four inner $\mathrm{NH}$ protons broad

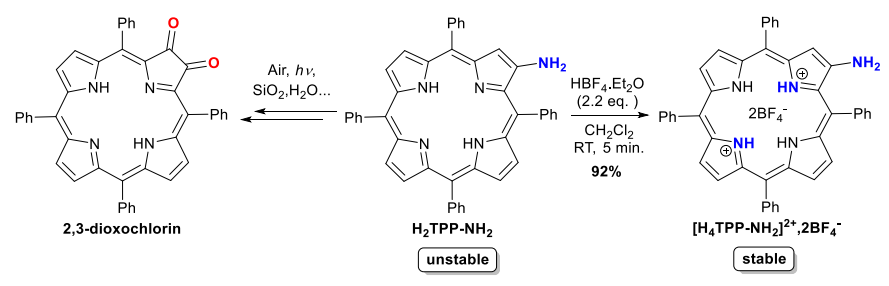

Scheme 3 Protonation of $\mathbf{H}_{2} \mathrm{TPP}-\mathrm{NH}_{\mathbf{2}}$ leading to air and light-stable $\left[\mathrm{H}_{4} \mathrm{TPP}-\mathrm{NH}_{\mathbf{2}}\right]^{2+}, \mathbf{2 B F}_{4}$ -

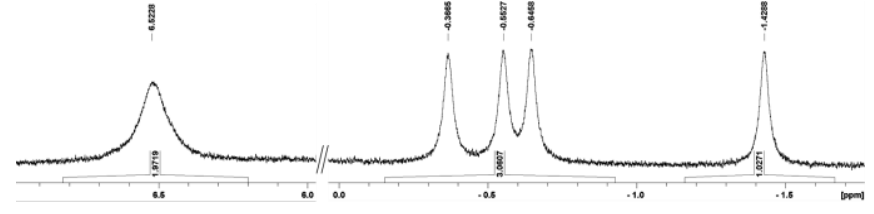

Fig. 1 Partial ${ }^{1} \mathrm{H}$ NMR of $\left[\mathrm{H}_{4} \mathrm{TPP}^{-\mathrm{NH}_{2}}\right]^{2+}, \mathbf{2} \mathrm{BF}_{4}^{-}\left(\left(\mathrm{CD}_{3}\right)_{2} \mathrm{SO}, 298 \mathrm{~K}, 600 \mathrm{MHz}\right)$.

singlets appear at distinct chemical shifts $(-0.37,-0.55$, -0.65 and $-1.43 \mathrm{ppm})$, each signal integrating for one proton while the amine function broad signal integrating for two protons is located at $6.52 \mathrm{ppm}$ (Fig. 1). As [ $\left.\mathbf{H}_{4} \mathbf{T P P}^{\mathrm{T}} \mathbf{N H}_{\mathbf{2}}\right]^{2+}, \mathbf{2} \mathbf{B F}_{4}{ }^{-}$ is stable in the solid state for more than two years at room temperature without protection from light and air, it could be used as a valuable precursor of $\mathbf{H}_{\mathbf{2}} \mathbf{T P P}-\mathbf{N H}_{\mathbf{2}}$ via its deprotonation. Interestingly, according to these results, the inner imine functions appear to be more basic than the amine function. This superior basicity for the inner imine moieties vs. the amine one was also observed in the 70's by Fuhrhop with meso-aminooctaethylporphyrin. ${ }^{23}$ As for aniline, the low basicity of the amine function may arise from the delocalization of the lone pair on the nitrogen atom into the $\pi$ system of the porphyrin. $\mathbf{H}_{\mathbf{2}} \mathbf{D T P}-\mathbf{N H}_{\mathbf{2}}$ behaves similarly upon protonation (compare Fig. S1 and Fig. S2-S4) but as this aminoporphyrin is stable under an air atmosphere, its protonation is less useful for its long-term storage.

Suitable single crystals for $\mathrm{X}$-ray diffraction analysis were obtained by slow diffusion of $\mathrm{Et}_{2} \mathrm{O}$ into a concentrated $\mathrm{CH}_{2} \mathrm{Cl}_{2}$ solution of $\left[\mathbf{H}_{4} \mathrm{TPP}-\mathrm{NH}_{2}\right]^{2+}, \mathbf{2} \mathrm{BF}_{4}{ }^{-}$in the dark. To our surprise, the molecular structure did not match the anticipated dicationic porphyrin but corresponded to the unstable $\mathbf{H}_{\mathbf{2}} \mathbf{T P P}-\mathbf{N H}_{\mathbf{2}}$ (Fig. 2, see ESI p. S14 for explanations) which X-ray crystallographic structure had never been reported. In the crystal, each porphyrin interacts with six other porphyrins via hydrogen bonds and $\mathrm{C}-\mathrm{H} \cdots \pi$ interactions. The $\mathrm{C} 2-\mathrm{N} 3$ bond distance is $1.367(3) \AA$. The primary amine moiety is hydrogen-bonded with the inner imine of another porphyrin $(d(\mathrm{~N}-\mathrm{H} \cdots \mathrm{N})=3.001(4) \AA$, $\left.\mathrm{N}-\mathrm{H} \cdots \mathrm{N}=135.7(2)^{\circ}\right)$.

In conclusion, efficient amination of free base porphyrins has been performed in two steps via anodic pyridination and subsequent ring-opening of the intermediate pyridinium derivatives with piperidine leading to the amines. This very regioselective route is competitive with other chemical pathways and is potentially applicable to other porphyrins and aromatics. Moreover, the diprotonation of the unstable $\mathbf{H}_{\mathbf{2}}$ TPP$\mathbf{N H}_{\mathbf{2}}$ allows for its long-term storage. It is foreseen that this very
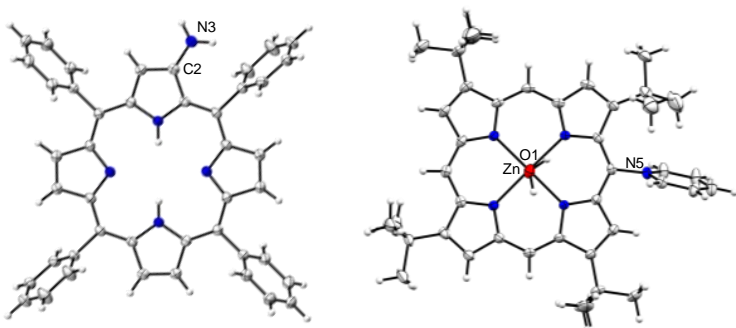

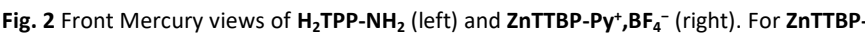
$\mathrm{Py}^{+}, \mathrm{BF}_{4}{ }^{-}$, two $\mathrm{CH}_{2} \mathrm{Cl}_{2}$ molecules, one $\mathrm{H}_{2} \mathrm{O}$ molecule with partial occupation and one $\mathrm{BF}_{4}{ }^{-}$ anion were omitted for clarity. Thermal ellipsoids are scaled to the $50 \%$ probability level. 
simple protonation method could be potentially useful to stabilize other unstable aminoporphyrins. Work is underway to extend the scope of these reactions and to exploit these aminoporphyrin derivatives.

This work was supported by the CNRS, Université Bourgogne Franche Comté, Conseil Régional de Bourgogne through the "Plan d'Actions Régional pour I'Innovation (PARI) and the "Fonds Européen de Développement Régional" (FEDER) programs. A.B. acknowledges the MESRI for a PhD grant. C.H.D. thanks the CNRS (Sept. 2015, one year "délégation CNRS") and the ANR for funding (ANR-15-CE29-0018-01). A.M.M. and C.H.D. thanks the French "Investissement d'Avenir" program, project ISITE-BFC (contract ANR-15-IDEX-03) for funding. The authors are thankful to Dr. B. Habermeyer (PorphyChem Company) for generous gift of $\mathbf{H}_{\mathbf{2}}$ TPP sample, to $\mathrm{S}$. Fournier for technical support and to the "Plateforme d'Analyse Chimique et de Synthèse Moléculaire de l'Université de Bourgogne".

\section{Conflicts of interest}

There are no conflicts to declare.

\section{Notes and references}

1. K. M. Kadish, K. M. Smith and R. Guilard, Handbook of Porphyrin Science (Volumes 1-40).

2. (a) M. Urbani, M. Gratzel, M. K. Nazeeruddin and T. Torres, Chem. Rev. (Washington, DC, U. S.), 2014, 114, 12330; (b) T. Higashino and H. Imahori, Dalton Trans., 2015, 44, 448; (c) Ö. Birel, S. Nadeem and H. Duman, J. Fluoresc., 2017, 27, 1075.

3. (a) Y. Chen and X. P. Zhang, J. Org. Chem., 2003, 68, 4432; (b) C. Liu, D.-M. Shen and Q.-Y. Chen, J. Org. Chem., 2007, 72, 2732; (c) G.-Y. Gao, J. V. Ruppel, D. B. Allen, Y. Chen and X. P. Zhang, J. Org. Chem., 2007, 72, 9060; (d) R. Sakamoto, M. Nishikawa, T. Yamamura, S. Kume and H. Nishihara, Chem. Commun., 2010, 46, 2028; (e) A. M. V. M. Pereira, M. G. P. M. S. Neves, J. A. S. Cavaleiro, C. Jeandon, J.-P. Gisselbrecht, S. Choua and R. Ruppert, Org. Lett., 2011, 13, 4742; (f) J. Haumesser, J.-P. Gisselbrecht, J. Weiss and R. Ruppert, Chem. Commun., 2012, 48, 11653; (g) K. Ladomenou, T. Lazarides, M. K. Panda, G. Charalambidis, D. Daphnomili and A. G. Coutsolelos, Inorg. Chem., 2012, 51, 10548-10556; (h) N. Fukui, W.-Y. Cha, S. Lee, S. Tokuji, D. Kim, H. Yorimitsu and A. Osuka, Angew. Chem. Int. Ed., 2013, 52, 9728 ; (i) A. Nowak-Król and D. T. Gryko, Org. Lett., 2013, 15, 5618; (j) J. Haumesser, A. M. V. M. Pereira, J.-P. Gisselbrecht, K. Merahi, S. Choua, J. Weiss, J. A. S. Cavaleiro and R. Ruppert, Org. Lett., 2013, 15,6282 .

4. Q. Cheng, Y.-H. Qiu, S.-L. Luo, L. Shuai, Y. Yuan, Y.-C. Chen and Q. Ouyang, Org. Lett., 2017, 19, 3871.

5. N. Fukui, H. Yorimitsu and A. Osuka, Angew. Chem. Int. Ed., 2015, 54, 6311.

6. C. H. Devillers, S. Hebié, D. Lucas, H. Cattey, S. Clément and S. Richeter, J. Org. Chem., 2014, 79, 6424.

7. M. C. Balaban, C. Chappaz-Gillot, G. Canard, O. Fuhr, C. Roussel and T. S. Balaban, Tetrahedron, 2009, 65, 3733.

8. (a) T. E. O. Screen, I. M. Blake, L. H. Rees, W. Clegg, S. J. Borwick and H. L. Anderson, J. Chem. Soc., Perkin Trans. I, 2002, 1, 320; (b) N. P. Redmore, I. V. Rubtsov and M. J. Therien, Inorg. Chem., 2002, 41, 566; (c) N. Yoshida, T. Ishizuka, K. Yofu, M. Murakami,
H. Miyasaka, T. Okada, Y. Nagata, A. Itaya, H. S. Cho, D. Kim and A. Osuka, Chem. Eur. J., 2003, 9, 2854; (d) T. Kamada, N. Aratani, T. Ikeda, N. Shibata, Y. Higuchi, A. Wakamiya, S. Yamaguchi, K. S. Kim, Z. S. Yoon, D. Kim and A. Osuka, J. Am. Chem. Soc., 2006, 128, 7670; (e) S. Wallin, C. Monnereau, E. Blart, J.-R. Gankou, F. Odobel and L. Hammarström, J. Phys. Chem. A, 2010, 114, 1709; (f) M. Matsumura, A. Tanatani, I. Azumaya, H. Masu, D. Hashizume, H. Kagechika, A. Muranaka and M. Uchiyama, Chem. Commun., 2013, 49, 2290; (g) S. Ito, S. Hiroto, S. Lee, M. Son, I. Hisaki, T. Yoshida, D. Kim, N. Kobayashi and H. Shinokubo, J. Am. Chem. Soc., 2015, 137, 142; (h) K.-i. Yamashita, K. Kataoka, S. Takeuchi and K.-i. Sugiura, J. Org. Chem., 2016, 81, 11176; (i) I. A. Abdulaeva, K. P. Birin, J. Michalak, A. Romieu, C. Stern, A. Bessmertnykh-Lemeune, R. Guilard, Y. G. Gorbunova and A. Y. Tsivadze, New J. Chem., 2016, 40, 5758.

9. (a) J. C. Fanning, T. L. Gray and N. Datta-Gupta, J. Chem. Soc., Chem. Commun., 1974, 23b; (b) M. M. Catalano, M. J. Crossley, M. M. Harding and L. G. King, J. Chem. Soc., Chem. Commun., 1984, 1535; (c) L. C. Gong and D. Dolphin, Can. J. Chem., 1985, 63, 401; (d) A. Wickramasinghe, L. Jaquinod, D. J. Nurco and K. M. Smith, Tetrahedron, 2001, 57, 4261.

10. (a) G. H. Barnett and K. M. Smith, J. Chem. Soc., Chem. Commun., 1974, 772; (b) J. E. Baldwin, M. J. Crossley and J. DeBernardis, Tetrahedron, 1982, 38, 685.

11. (a) K. M. Smith, G. H. Barnett, B. Evans and Z. Martynenko, J. Am. Chem. Soc., 1979, 101, 5953; (b) S. Hebié, A. K. D. Dimé, C. H. Devillers and D. Lucas, Chem. Eur. J., 2015, 21, 8281.

12. (a) A. W. Johnson and D. Oldfield, J. Chem. Soc., 1965, 4303; (b) A. Mikus, M. Zając and S. Ostrowski, Organic Chemistry Frontiers, 2018, 5, 2840.

13. E. Watanabe, S. Nishimura, H. Ogoshi and Z. Yoshida, Tetrahedron, 1975, 31, 1385.

14. S. Yang, B. Sun, Z. Ou, D. Meng, G. Lu, Y. Fang and K. M. Kadish, J. Porphyrins Phthalocyanines, 2013, 17, 857.

15. (a) C. Matlachowski and M. Schwalbe, Dalton Trans., 2013, 42 3490; (b) M. Handayani, S. Gohda, D. Tanaka and T. Ogawa, Chem. Eur. J., 2014, 20, 7655.

16. M. Lo, J.-F. Lefebvre, D. Leclercq, A. van der Lee and S. Richeter, Org. Lett., 2011, 13, 3110.

17. D. P. Arnold, R. C. Bott, H. Eldridge, F. M. Elms, G. Smith and M. Zojaji, Aust. J. Chem., 1997, 50, 495.

18. L. J. Esdaile, M. O. Senge and D. P. Arnold, Chem. Commun., 2006, 4192.

19. Y. Y. Enakieva, J. Michalak, I. A. Abdulaeva, M. V. Volostnykh, C. Stern, R. Guilard, A. G. Bessmertnykh-Lemeune, Y. G. Gorbunova, A. Y. Tsivadze and K. M. Kadish, Eur. J. Org. Chem., 2016, 2016, 4881.

20. T. Morofuji, A. Shimizu and J.-i. Yoshida, J. Am. Chem. Soc., 2013, 135,5000 .

21. (a) L. El Kahef, M. El Meray, M. Gross and A. Giraudeau, J. Chem. Soc., Chem. Commun., 1986, 621; (b) J. A. S. Cavaleiro, M. G. P. M. S. Neves, M. J. E. Hewlins and A. H. Jackson, J. Chem. Soc., Perkin Trans. I, 1986, 575; (c) L. El Kahef, M. Gross and A. Giraudeau, J. Chem. Soc., Chem. Commun., 1989, 963; (d) L. Ruhlmann and A. Giraudeau, Chem. Commun., 1996, 2007; (e) C. H. Devillers, A. K. D. Dimé, H. Cattey and D. Lucas, Chem. Commun., 2011, 47, 1893; (f) D. Schaming, S. Marggi-Poullain, I. Ahmed, R. Farha, M. Goldmann, J.-P. Gisselbrecht and L. Ruhlmann, New J. Chem., 2011, 35, 2534.

22. M. J. Crossley and L. G. King, J. Chem. Soc., Chem. Commun., 1984, 920.

23. J. H. Fuhrhop, J. Chem. Soc. D, Chem. Commun., 1970, 781. 